\title{
Determinanty konkurencyjności przedsiębiorstw wcześnie umiędzynarodowionych
}

\author{
Dr hab. Mirosław Jarosiński, prof. SGH iD \\ Szkoła Główna Handlowa w Warszawie \\ Kolegium Gospodarki Światowej \\ Katedra Zarządzania Międzynarodowego
}

\section{Wprowadzenie}

Konkurencyjność przedsiębiorstwa może być rozpatrywana w różny sposób, na przykład jako efektywność, skuteczność czy sprawność przedsiębiorstwa ${ }^{1}$. Może też być rozumiana jako zdolność dostosowania się przedsiębiorstwa do przewidywanych zmian warunków otoczenia ${ }^{2}$ czy też jako zdolność do sprawnego rywalizowania $z$ innymi przedsiębiorstwami dla osiągnięcia takich samych celów na danym rynku ${ }^{3}$. Z punktu widzenia zarządzania strategicznego należy spojrzeć na konkurencyjność przedsiębiorstwa jako na zdolność do osiągania przewagi nad innymi uczestnikami sektora ${ }^{4}$, a szczególnie trwałej przewagi konkurencyjnej.

Celem niniejszego rozdziału jest określenie determinant konkurencyjności przedsiębiorstw podejmujących wczesną internacjonalizację na podstawie analizy dostępnej literatury przedmiotu.

Opracowanie składa się z dwóch części i zakończenia. Najpierw następuje krótka prezentacja zjawiska wczesnej internacjonalizacji przedsiębiorstw, po której autor

1 Z. Pierścionek, Strategie konkurencji i rozwoju przedsiębiorstwa, Wydawnictwo Naukowe PWN, Warszawa 2003, s. 165.

2 H.G. Adamkiewicz-Drwiłło, H.M. Kruk, Konkurencyjność ekologiczna jako jeden z aspektów strategicznej konkurencyjności przedsiębiorstw, [w:] Z. Dworzecki, M. Romanowska (red.), Strategie przedsiębiorstw w otoczeniu globalnym, Oficyna Wydawnicza SGH - Szkoła Gtówna Handlowa w Warszawie, Warszawa 2008, s. 144.

3 M.J. Stankiewicz, Konkurencyjność przedsiębiorstwa. Budowanie konkurencyjności przedsiębiorstwa w warunkach globalizacji, Towarzystwo Naukowe Organizacji i Kierownictwa, Toruń 2002, s. 36.

4 J. Skalik, Rynkowe i pozarynkowe uwarunkowania wzrostu konkurencyjności małych i średnich przedsiębiorstw, [w:] R. Krupski (red.), Zarzq̨dzanie strategiczne. Strategie małych firm, „Prace Naukowe WWSZiP”, seria „Zarządzanie i Marketing”, Wałbrzych 2005. 
dokonuje analizy literatury w zakresie konkurencyjności przedsiębiorstw wcześnie umiędzynarodowionych i jej determinant. W zakończeniu zostały natomiast przedstawione wnioski z przeprowadzonej analizy.

\section{Wczesna internacjonalizacja przedsiębiorstw}

Wczesna internacjonalizacja przedsiębiorstw jest zjawiskiem obserwowanym od początku lat dziewięćdziesiątych ubiegłego wieku, kiedy zaczęły pojawiać się pierwsze doniesienia na temat przedsiębiorstw wcześnie umiędzynarodowionych ${ }^{5}$, co stało się przyczynkiem do badań nad zjawiskiem wczesnej internacjonalizacji - zaprzeczającym teorii internacjonalizacji etapowej, uznawanej wtedy za powszechną i niepodważalną.

Badania dotyczyły między innymi skali występowania tego zjawiska, porównań przedsiębiorstw wcześnie umiędzynarodowionych do innego typu przedsiębiorstw (w tym w szczególności rozwijających się etapowo), czynników wpływających na powstawanie przedsiębiorstw wcześnie umiędzynarodowionych, ich strategii, czynników sukcesu wczesnej internacjonalizacji, wpływu wczesnej internacjonalizacji na wyniki przedsiębiorstw, powiązań sieciowych przedsiębiorstw wcześnie umiędzynarodowionych. Mimo powstania wielu opracowań badawczych i publikacji zjawisko wczesnej internacjonalizacji nie jest do końca wyjaśnione ani zdefiniowane ${ }^{6}$.

Wczesna internacjonalizacja jest też kontestowana przez niektórych badaczy, na przykład przez Hennarta ${ }^{7}$, który uważa, że przedsiębiorstwa wcześnie umiędzynarodowione nie stanowią odrębnej kategorii, a jedynie są emanacją innego modelu biznesowego ${ }^{8}$. Z kolei inni badacze, między innymi Almodóvar i Rugman, podważają znaczenie zjawiska wczesnej internacjonalizacji, mówiąc o efekcie iluzji urodzonych globalistów (born global illusion) ${ }^{9}$, czy Braunerhjelm i Halldi, którzy - przebadawszy

5 Patrz: M.W. Rennie, Global Competitiveness: Born Global, „McKinsey Quarterly” 1993, vol. 4; P.P. McDougall, S. Shane, B. Oviatt, Explaining the Formation of International New Ventures: The Limits of Theories from International Business Research, „Journal of Business Venturing” 1994, vol. 9, no. 6 .

6 Wciąż nie ma porozumienia pomiędzy badaczami na temat określeń terminologicznych i definicji przedsiębiorstw wcześnie umiędzynarodowionych. Patrz szerzej: M. Jarosiński, Procesy i modele internacjonalizacji przedsiębiorstw, Oficyna Wydawnicza SGH - Szkoła Główna Handlowa w Warszawie, Warszawa 2013, s. 186-214. Mimo iż od wskazanej publikacji upłynęło już kilka lat, sytuacja w tym zakresie nie poprawita się, a nawet pojawiają się nowe terminy na określenie przedsiębiorstw wcześnie umiędzynarodowionych.

7 Patrz: J.-F. Hennart, The Accidental Internationalists: A Theory of Born Globals, „Entrepreneurship Theory and Practice", January 2014.

8 Tamże.

9 Patrz: P. Almodóvar, A.M. Rugman, The M Curve and the performance of Spanish International New Ventures, „British Journal of Management” 2014, vol. 25. 
wszystkie szwedzkie start-upy produkcyjne powstałe w latach 1998-2008 - konkludują, że w rzeczywistości urodzeni globaliści są bardzo rzadkim zjawiskiem ${ }^{10}$.

W tym opracowaniu przyjmuje się najczęściej stosowaną w literaturze definicję przedsiębiorstw wcześnie umiędzynarodowionych ${ }^{11}$. Przedsiębiorstwa te są zdefiniowane jako podejmujące internacjonalizację w momencie uruchamiania działalności lub niedługo po jej rozpoczęciu, nie później jednak niż w trzecim roku działalności i osiągające minimum 25\% przychodów ze sprzedaży za granicą. Są to przeważnie małe i średnie przedsiębiorstwa, które mimo ograniczonych zasobów (materialnych i niematerialnych) są w stanie nie tylko wejść na wiele rynków zagranicznych, ale również działać na nich w długim okresie ${ }^{12}$, często osiągając lepsze wyniki niż firmy międzynarodowe działające dużo dłużej od nich.

Literatura przedmiotu wskazuje też na pewne podobieństwa przedsiębiorstw wcześnie umiędzynarodowionych do dużych przedsiębiorstw obecnych na rynku międzynarodowym od wielu lat. Z badań Moena wynika, że jeśli chodzi o przewagę konkurencyjną, strategię eksportową, orientację globalną i pozycję na rynku firmy skategoryzowane jako „nowe i globalne” nie różnią się znacząco od firm wysoce umiędzynarodowionych, działających od kilku dziesięcioleci, określonych w jego badaniu jako „stare i globalne”13.

\section{Konkurencyjność przedsiębiorstw wcześnie umiędzynarodowionych}

W odniesieniu do konkurencyjności przedsiębiorstw wcześnie umiędzynarodowionych analizuje się przede wszystkim ich efektywność. Badaniom podlegają relacje pomiędzy wczesną internacjonalizacją przedsiębiorstw a ich wynikami. Przykładowo: Kuivalainen i inni bezpośrednio wiążą w swoim modelu badawczym wyniki przedsiębiorstw z ich przewagą konkurencyjną i uzależniają je od przyjętej

10 P. Braunerhjelm, T. Halldi, Born globals - presence, performance and prospects, „International Business Review" 2019, vol. 28, s. 60-73.

11 Patrz: M. Jarosiński, Urodzeniglobaliści w badaniach na świecie i w Polsce, „Studia i Prace Kolegium Zarządzania i Finansów” nr 114, Szkoła Główna Handlowa w Warszawie, Warszawa 2012, s. 15.

12 Przykładowo: Almor, Tarba i Margalit prowadzili badania na grupie izraelskich urodzonych globalistów funkcjonujących na rynku już ponad 20 lat. Patrz szerzej na ten temat w: T. Almor, S.Y. Tarba, A. Margalit, Maturing, Technology-Based, Born-Global Companies: Surviving Through Mergers and Acquisitions, „Management International Review” 2014, vol.54, no. 4. Również autor niniejszego opracowania prowadzit badania na grupie wcześnie umiędzynarodowionych przedsiębiorstw, które w momencie prowadzenia badań funkcjonowały na rynku już od 16 do 24 lat.

$13 \varnothing$. Moen, The Born Globals. A new generation of small European exporters, „International Marketing Review" 2002, vol. 19, no. 2, s. 167. 
ścieżki globalizacji ${ }^{14}$. Według badaczy te przedsiębiorstwa, które rzeczywiście realizowały globalną ekspansję, uzyskiwały wyniki powyżej średniej dla sektora, podczas gdy firmy koncentrujące się na mniejszym zasięgu międzynarodowym (określone przez nich jako born internationals) miały słabsze wyniki ${ }^{15}$.

Z kolei według Knighta i Cavusgila wyniki przedsiębiorstw zależą od przyjętych strategii i kompetencji firm ${ }^{16}$. Ich zdaniem na ponadprzeciętne wyniki działalności międzynarodowej (rozumiane tu jako stopień realizacji celów) mają wpływ międzynarodowa orientacja przedsiębiorcza i międzynarodowa orientacja marketingowa, które kształtują strategie biznesowe tych firm ${ }^{17}$. Natomiast Jantunen i współautorzy uznają, że silna orientacja przedsiębiorcza i orientacja na rozwój na rynkach międzynarodowych to warunki konieczne, aby stać się firmą wcześnie umiędzynarodowioną, natomiast na wyniki tego typu przedsiębiorstw ma pozytywny wpływ przede wszystkim orientacja na uczenie się ${ }^{18}$.

$\mathrm{Na}$ istotność uczenia się w procesie ekspansji międzynarodowej małych i średnich przedsiębiorstw, nastawionej na osiąganie dobrych wyników oraz zdobycie i utrzymanie mocnej pozycji konkurencyjnej, zwracają również uwagę Zahra, Ireland i Hitt ${ }^{19}$. Uważają oni, że przedsiębiorstwa wcześnie umiędzynarodowione są szczególnie dobre w integracji wiedzy o działalności międzynarodowej, co pozwala im zdobywać przewagę konkurencyjną w stosunku do konkurentów od dawna istniejących na rynku20.

Również ostatnie badania przedsiębiorstw wcześnie umiędzynarodowionych z Europy Środkowo-Wschodniej potwierdzają dużą wagę uczenia się w osiąganiu ich konkurencyjności. Ciszewska-Mlinarič, Wójcik i Obłój opisują przedsiębiorstwo wcześnie umiędzynarodowione, powstałe na początku lat dziewięćdziesiątych ubiegłego wieku, które dzięki uczeniu się rozwijało się dynamicznie na rynkach międzynarodowych, przekształcając z czasem w korporację transnarodową ${ }^{21}$.

14 O. Kuivalainen, S. Sundqvist, P. Servais, Firm's Degree of Born-Globalness, International Entrepreneurial Orientation and Export Performance, „Journal of World Business” 2007, vol. 42, s. 259.

15 Tamże, s. 265.

16 G.A. Knight, S.T. Cavusgil, Innovation, Organization Capabilities, and the Born-Global Firm, „Journal of International Business Studies” 2004, vol. 35, no. 2, s. 129.

17 Tamże.

18 A. Jantunen i wsp., Strategic Orientations of Born Globals - Do They Really Matter?, „Journal of World Business" 2008, vol. 43, s. 167.

19 S.A. Zahra, D.R. Ireland, M.A. Hitt, International Expansion by New Venture Firms: International Diversity, Mode of Market Entry, Technological Learning and Performance, „Academy of Management Journal" 2000, vol. 43, no. 5.

20 Tamże s. 930.

21 M. Ciszewska-Mlinarič, P. Wójcik, K. Obłój, Learning dynamics of rapidly internationalizing venture: Beyond the early stage of international growth in a CEE context, „Journal of Business Research" 2020, vol. 108, s. 450-465, https://doi.org/10.1016/j.jbusres.2019.03.002 
Z badań Knighta, Madsena i Servaisa wynika, że w tworzeniu międzynarodowych wyników działalności przedsiębiorstw wcześnie umiędzynarodowionych szczególnie ważne są jakość i różnicowanie produktu oraz kompetencje marketingowe firm ${ }^{22}$. Baranowska-Prokop i Sikora zidentyfikowali zależność pomiędzy lepszą strategią produktu, powiązaną z jego wysoką jakością, a postrzeganiem sukcesu finansowego firmy ${ }^{23}$.

Interesujące badania na temat wyników eksportu firm australijskich przedstawili Lu i Julian, którzy udowodnili, że międzynarodowe doświadczenie menedżerów, ich kompetencje i zaangażowanie mają pozytywny wpływ na wyniki eksportowe firm, ponieważ sformalizowane planowanie i zaangażowanie odpowiednich zasobów redukują ryzyko działalności i prowadzą do lepszych wyników ${ }^{24}$.

Drugim ważnym nurtem badań nad konkurencyjnością przedsiębiorstw wcześnie umiędzynarodowionych są stosowane przez nie strategie konkurencji. Przedsiębiorstwa wcześnie umiędzynarodowione przeważnie stosują strategię wyróżniania w niszy globalnej. Tak wynika na przykład z badań Larimo i Pulkkinen ${ }^{25}$, Luostarinena i Gabrielssona ${ }^{26}$ czy Laantiego, Gabrielssona i Gabrielssona ${ }^{27}$. Badania wymienionych autorów pokazują, że w większości przypadków przewaga konkurencyjna opiera się na jakości, technologii i pierwszeństwie na rynku.

Trzeba jednak pamiętać, że przewaga technologiczna może zanikać wraz z wiekiem i wzrostem firmy ${ }^{28}$. Potwierdzają to też badania Almor, Tarby i Margalit, przeprowadzone na próbie izraelskich technologicznych urodzonych globalistów, które pokazują, że po dwudziestu latach działalności samodzielnie przetrwało tylko 70\%

22 G. Knight, T.K. Madsen, P. Servais, An inquiry into born-global firms in Europe and the USA, „International Marketing Review” 2004, vol. 21, no. 6, s. 653.

23 E. Baranowska-Prokop, T. Sikora, Competitive strategy versus sector-specific determinants in success perception of Polish born globals, „Journal of International Studies” 2015, vol. 8, no 1, s. 19; T. Sikora, E. Baranowska-Prokop, Explaining success perception of Polish international new ventures: Four perspectives, „Economics and Sociology” 2018, vol. 11, no. 4, s. 124.

24 V.N. Lu, C.C. Julian, The Internet, Strategy and Performance: A Study of Australian Export Market Ventures, „Journal of Global Marketing” 2008, vol. 21, no. 3, s. 238.

25 Zob. J. Larimo, J. Pulkkinen, Global Orientation, Competitive Advantages and Export Strategies of Different Types of SMEs: Empirical Evidence from Finland, Proceedings of the $28^{\text {th }}$ Annual Conference of European International Business Academy (EIBA), Athens 2002, s. 21-22.

26 Zob. R. Luostarinen, M. Gabrielsson, Globalization and Marketing Strategies of Born Globals in SMOPECS, „Thunderbird International Business Review” 2006, vol. 48, no. 6, s. 785-786.

27 Zob. R. Laanti, M. Gabrielsson, P. Gabrielsson, The globalization strategies of business-to-business born global firms in the wireless technology industry, „Industrial Marketing Management" 2007, vol. 36, s. 1105.

$28 \varnothing$. Moen, P. Servais, Born Global or Gradual Global? Examining the Export Behavior of Small and Medium-Sized Enterprises, „, Journal of International Marketing” 2002, vol. 10, no. 3, s. 67. 
przedsiębiorstw. Większość z nich nie była w stanie utrzymać przewagi technologicznej i musiała dokonywać przejęć i akwizycji, aby podtrzymywać swój wzrost, a wyniki przedsiębiorstw w drugiej dekadzie działalności były słabsze niż w pierwszej29.

Zander, McDougall-Covin i Rose widzą kilka możliwych ścieżek rozwoju urodzonych globalistów. Według nich założyciele tych firm mogą je sprzedać, ale też moga je dalej rozwijać na drodze kolejnych przełomowych innowacji. Firmy te mogą również rozwijać się w sposób tradycyjny, wchodząc ze swoimi produktami na nowe rynki i/lub zwiększając swoje udziały rynkowe w poszczególnych krajach ${ }^{30}$.

Knight i Cavusgil podkreślają znaczenie bardzo wysokiej jakości produktów przedsiębiorstw wcześnie umiędzynarodowionych dla ich konkurencyjności ${ }^{31}$. Jednak Skalik zwraca uwagę, że o konkurencyjności przedsiębiorstwa decyduje nie tylko sam produkt, ale też sposób jego dostarczenia i poziom obsługi posprzedażnej ${ }^{32}$. Tak samo Larimo i Pulkkinen zauważają na przykład znaczenie sprzedaży osobistej ${ }^{33}$, a Luostarinen i Gabrielsson znaczenie sprzedaży bezpośrednio do klienta ${ }^{34}$.

Na konkurencyjność przedsiębiorstw wcześnie umiędzynarodowionych wpływa również zakorzenienie w lokalnych sieciach. Lokalne sieci i implikowana dzięki nim wiedza stanowiły źródło przewagi konkurencyjnej na rynku globalnym przedsiębiorstw badanych przez Kudinę, Yipa i Barkemę ${ }^{35}$.

W tym miejscu warto zauważyć, że na aspekt tworzenia przewagi konkurencyjnej przez przedsiębiorstwa wcześnie umiędzynarodowione wskazuje już pierwsza definicja international new ventures stworzona przez Oviata i McDougal, mówiąca, że international new ventures to „przedsiębiorstwa, które od samego powstania dążą do uzyskania znaczącej przewagi konkurencyjnej, wykorzystując zasoby i sprzedając swoje produkty w wielu krajach"36.

Determinant konkurencyjności można upatrywać na przykład w źródłach przewagi konkurencyjnej przedsiębiorstw. Cavusgil i Knight zauważają, że w literaturze dotyczącej internacjonalizacji przedsiębiorstw, a zwłaszcza przedsiębiorstw wcześnie umiędzynarodowionych, jako źródła przewagi konkurencyjnej wymienia się

29 T. Almor, S.Y. Tarba, A. Margalit, Maturing..., s. 429-430 i 437-438.

30 I. Zander, P. McDougall-Covin, E.L. Rose, Born globals and international business: Evolution of a field of research, „Journal of International Business Studies” 2015, vol. 46, no. 1, s. 31.

31 G.A. Knight, S.T. Cavusgil, Innovation, organizational capabilities..., s. 131.

32 J. Skalik, Rynkowe i pozarynkowe...

33 J. Larimo, J. Pulkkinen, Global Orientation..., s. 20-21.

34 R. Luostarinen, M. Gabrielsson, Globalization and Marketing..., s. 785-786.

35 A. Kudina, G.S. Yip, H.G. Barkema, Born Global, „Business Strategy Review”, Winter 2008, S. 42-43.

36 B.M. Oviatt, P.P. McDougall, Toward a Theory of International New Ventures, „Journal of International Business Studies" 1994, vol. 25, no. 1, s. 49. 
orientację przedsiębiorczą firmy, koncentrację na innowacjach, zdolność do utrzymania przywództwa technologicznego, aktywne angażowanie się w sieci biznesowe oraz podejmowanie ryzyka przy jednoczesnym wykorzystywaniu pojawiających się okazji biznesowych ${ }^{37}$. Z kolei Knight, Madsen i Servais zauważają, że aby uzyskać i utrzymać przewagę konkurencyjną na rynku międzynarodowym, przedsiębiorstwa wcześnie umiędzynarodowione muszą zarządzać zasobami, które są rzadkie i/lub wyróżniające się, a dla nich charakterystyczne ${ }^{38}$.

Kaura i Sandhub podkreślają, że źródłami przewagi konkurencyjnej przedsiębiorstw podejmujących wczesną internacjonalizację są zasoby, wiedza i doświadczenie, ale nie samych przedsiębiorstw wcześnie umiędzynarodowionych, tylko ich założycieli ${ }^{39}$. Zdaniem Laantiego, Gabrielsson i Gabrielssona przedsiębiorstwa wcześnie umiędzynarodowione są w stanie zamknąć „lukę zasobową” w stosunku do dużych konkurentów, wykorzystując rozległą wiedzę i umiejętności uprzednio pozyskane właśnie przez ich założycieli ${ }^{40}$. Wpływ umiejętności założycieli i ich bezpośredniego otoczenia społecznego oraz tzw. osobistych zasobów przedsiębiorcy między innymi na wczesną internacjonalizację potwierdzają też badania Wąsowskiej ${ }^{41}$.

Źródłem przewag konkurencyjnych mogą być również sieci, w których funkcjonują założyciele przedsiębiorstw wcześnie umiędzynarodowionych ${ }^{42}$. Aspekt funkcjonowania w sieci jest niezwykle istotny i już dość dobrze opisany w literaturze przedmiotu. Baum, Calabrese i Silverman uważają, że born globals uzyskują dzięki sieciom takie zasoby społeczne, technologiczne i handlowe, których zgromadzenie zajęłoby innym firmom całe lata ${ }^{43}$.

37 S.T. Cavusgil, G. Knight, The born global firm: An entrepreneurial and capabilities perspective on early and rapid internationalization, „Journal of International Business Studies” 2015, vol. 46, s. 3-16.

38 G. Knight, T.K. Madsen, P. Servais, An inquiry into born-global firms..., s. 648.

39 S. Kaura, M.S. Sandhub, Internationalisation of born global firms: Evidence from Malaysia, „Journal of the Asia Pacific Economy” 2013, vol. 19, no. 1, s. 123.

40 R. Laanti, M. Gabrielsson, P. Gabrielsson, The globalization strategies..., s. 1107.

41 A. Wąsowska, Przedsiębiorcy wobec okazji na rynkach zagranicznych. Mikrofundamenty umiędzynarodowienia firmy, Wydawnictwo Poltext, Warszawa 2019, s. 179-183.

42 S. Kaura, M.S. Sandhub, Internationalisation of born global firms..., s. 123.

43 J.A.C. Baum, T. Calabrese, B.S. Silverman, Don't go alone: Alliance network composition and startups' performance in Canadian biotechnology, „Strategic Management Journal” 2000, vol. 21, no. 3, za: R. Laanti, M. Gabrielsson, P. Gabrielsson, The globalization strategies..., s. 1107. 


\section{Zakończenie}

Celem niniejszego opracowania było określenie determinant konkurencyjności przedsiębiorstw podejmujących wczesną internacjonalizację. Jak wskazano na początku konkurencyjność przedsiębiorstwa, w tym przedsiębiorstwa wcześnie umiędzynarodowionego, może być rozumiana jako jego efektywność i/lub trwała przewaga konkurencyjna.

W analizowanych badaniach zidentyfikowano wiele czynników determinujących efektywność i przewagę konkurencyjną przedsiębiorstw. Dwa z nich powtarzały się w obydwu wątkach analizy. Zdaniem autora można je $\mathrm{z}$ tego powodu uznać za najważniejsze. Były to: orientacja na wiedzę (posiadanie, pozyskiwanie, przetwarzanie wiedzy i uczenie się organizacyjne) i orientacja marketingowa (bardzo wysoka jakość produktów, kontakt z klientem, kompetencje marketingowe). Poza tym ważnym czynnikiem determinującym wielkość przewagi konkurencyjnej jest zakorzenienie w lokalnych sieciach biznesowych. Drugim czynnikiem, który pojawia się w badaniach, jest kwestia innowacyjnej technologii. Tu jednak istnieje problem szybkiego starzenia się technologii, co powoduje konieczność stałego ich rozwijania lub pozyskiwania z zewnątrz. Może to ograniczać możliwości utrzymania przewagi konkurencyjnej w długim okresie.

\section{Bibliografia}

Adamkiewicz-Drwiłło H.G., Kruk H.M., Konkurencyjność ekologiczna jako jeden z aspektów strategicznej konkurencyjności przedsiębiorstw, [w:] Z. Dworzecki, M. Romanowska (red.), Strategie przedsiębiorstw w otoczeniu globalnym, Oficyna Wydawnicza SGH - Szkoła Główna Handlowa w Warszawie, Warszawa 2008, s. 141-157.

Almodóvar P., Rugman A.M., The M Curve and the performance of Spanish International New Ventures, „British Journal of Management” 2014, vol. 25, s. S6-S23.

Almor T., Tarba S.Y., Margalit A., Maturing, Technology-Based, Born-Global Companies: Surviving Through Mergers and Acquisitions, „Management International Review” 2014, vol. 54, no. 4, s. 421-444.

Baranowska-Prokop E., Sikora T., Competitive strategy versus sector-specific determinants in success perception of Polish born globals, „Journal of International Studies” 2015, vol. 8, no. 1, s. $9-21$.

Baum J.A.C., Calabrese T., Silverman B.S., Don't go alone: Alliance network composition and startups' performance in Canadian biotechnology, „Strategic Management Journal” 2000, vol. 21, no. 3, s. 267-294.

Braunerhjelm P., Halldi T., Born globals - presence, performance and prospects, „International Business Review" 2019, vol. 28, s. 60-73.

Cavusgil S.T., Knight G., The born global firm: An entrepreneurial and capabilities perspective on early and rapid internationalization, „Journal of International Business Studies” 2015, vol. 46, s. 3-16. 
Ciszewska-Mlinarič M., Wójcik P., Obłój K., Learning dynamics of rapidly internationalizing venture: Beyond the early stage of international growth in a CEE context, „Journal of Business Research" 2020, vol. 108, s. 450-465, https://doi.org/10.1016/j.jbusres.2019.03.002

Hennart J.-F., The Accidental Internationalists: A Theory of Born Globals, „Entrepreneurship Theory and Practice", January 2014, s. 117-135.

Jantunen A., Nummela N., Puumalainen K., Saarenketo S., Strategic Orientations of Born Globals - Do They Really Matter?, „Journal of World Business” 2008, vol. 43, s. 158-170.

Jarosiński M., Procesy i modele internacjonalizacji przedsiębiorstw, Oficyna Wydawnicza SGH - Szkoła Główna Handlowa w Warszawie, Warszawa 2013.

Jarosiński M., Urodzeni globaliści w badaniach na świecie i w Polsce, „Studia i Prace Kolegium Zarządzania i Finansów” nr 114, Szkoła Główna Handlowa w Warszawie, Warszawa 2012.

Kaura S., Sandhub M.S., Internationalisation of born global firms: Evidence from Malaysia, „Journal of the Asia Pacific Economy" 2013, vol. 19, no. 1, s. 101-136.

Knight G.A., Cavusgil S.T., Innovation, organizational capabilities, and the born-global firm, „Journal of International Business Studies" 2004, vol. 35, no. 2, s. 124-141.

Knight G., Madsen T.K., Servais P., An inquiry into born-global firms in Europe and the USA, „International Marketing Review" 2004, vol. 21, no. 6, s. 645-666.

Kudina A., Yip G.S., Barkema H.G., Born Global, „Business Strategy Review”, Winter 2008, s. 38-44.

Kuivalainen O., Sundqvist S., Servais P., Firm's Degree of Born-Globalness, International Entrepreneurial Orientation and Export Performance, „Journal of World Business” 2007, vol. 42, s. 253-267.

Laanti R., Gabrielsson M., Gabrielsson P., The globalization strategies of business-to-business born global firms in the wireless technology industry, „Industrial Marketing Management” 2007, vol. 36, s. 1104-1117.

Larimo J., Pulkkinen J., Global Orientation, Competitive Advantages and Export Strategies of Different Types of SMEs: Empirical Evidence from Finland, Proceedings of the $28^{\text {th }}$ Annual Conference of European International Business Academy (EIBA), Athens 2002.

Lu V.N., Julian C.C., The Internet, Strategy and Performance: A Study of Australian Export Market Ventures, „Journal of Global Marketing” 2008, vol. 21, no. 3, s. 231-240.

Luostarinen R., Gabrielsson M., Globalization and Marketing Strategies of Born Globals in SMOPECS, „Thunderbird International Business Review” 2006, vol. 48, no. 6, s. 773-800.

McDougall P.P., Shane S., Oviatt B., Explaining the Formation of International New Ventures: The Limits of Theories from International Business Research, „Journal of Business Venturing” 1994, vol. 9, no. 6, s. 469-487.

Moen $\varnothing$., The Born Globals. A new generation of small European exporters, „International Marketing Review" 2002, vol. 19, no. 2, s. 156-175.

Moen Ø., Servais P., Born Global or Gradual Global? Examining the Export Behavior of Small and Medium-Sized Enterprises, „Journal of International Marketing” 2002, vol. 10, no. 3, s. 49-72.

Oviatt B.M., McDougall P.P., Toward a Theory of International New Ventures, „Journal of International Business Studies" 1994, vol. 25, no. 1, s. 29-41.

Pierścionek Z., Strategie konkurencji i rozwoju przedsiębiorstwa, Wydawnictwo Naukowe PWN, Warszawa 2003.

Rennie M.W., Global Competitiveness: Born Global, „McKinsey Quarterly” 1993, vol. 4, s. 45-52.

Sikora T., Baranowska-Prokop E., Explaining success perception of Polish international new ventures: Four perspectives, „Economics and Sociology” 2018, vol. 11, no. 4, s. 106-127.

Skalik J., Rynkowe i pozarynkowe uwarunkowania wzrostu konkurencyjności małych i średnich przedsiębiorstw, [w:] R. Krupski (red.), Zarządzanie strategiczne. Strategie małych firm, „Prace Naukowe WWSZiP”, seria „Zarządzanie i Marketing”, Wałbrzych 2005. 
Stankiewicz M.J., Konkurencyjność przedsiębiorstwa. Budowanie konkurencyjności przedsiębiorstwa w warunkach globalizacji, Towarzystwo Naukowe Organizacji i Kierownictwa, Toruń 2002.

Wąsowska A., Przedsiębiorcy wobec okazji na rynkach zagranicznych. Mikrofundamenty umiędzynarodowienia firmy, Wydawnictwo Poltext, Warszawa 2019.

Zahra S.A., Ireland D.R., Hitt M.A., International Expansion by New Venture Firms: International Diversity, Mode of Market Entry, Technological Learning and Performance, „Academy of Management Journal" 2000, vol. 43, no. 5, s. 925-950.

Zander I., McDougall-Covin P.P., Rose E.L., Born globals and international business: Evolution of a field of research, „, Journal of International Business Studies” 2015, vol. 46, no. 1, s. 27-35.

\section{Streszczenie}

Rozdział przedstawia przegląd literatury dotyczącej konkurencyjności przedsiębiorstw wcześnie umiędzynarodowionych (international new ventures, born globals). Konkurencyjność przedsiębiorstw może być rozpatrywana na wiele sposobów. W odniesieniu do przedsiębiorstw wcześnie umiędzynarodowionych analizuje się przede wszystkim ich efektywność oraz strategie konkurencji. Analiza literatury prowadzi do wniosku, że najważniejsze determinanty to orientacja na wiedzę (posiadanie, pozyskiwanie, przetwarzanie wiedzy i uczenie się organizacyjne) i orientacja marketingowa (bardzo wysoka jakość produktów, kontakt z klientem, kompetencje marketingowe). Poza tym ważnym czynnikiem determinującym wielkość przewagi konkurencyjnej jest zakorzenienie w lokalnych sieciach biznesowych.

Słowa kluczowe: konkurencyjność, przedsiębiorstwa wcześnie umiędzynarodowione, international new ventures, born globals, wczesna internacjonalizacja

\section{Determinants of Competitiveness of Early-Internationalised Firms}

\section{Abstract}

The text presents a literature review on the competitiveness of early-internationalized firms (international new ventures, born globals). The competitiveness of enterprises can be tackled in many ways. In relation to early-internationalized firms, the main focus is on their effectiveness and competitive strategies. The analysis of the literature leads to the understanding that the most important determinants are knowledge orientation (possessing, acquiring, processing knowledge and organizational learning) and marketing orientation (very high quality of products, contact with the client, marketing competences). In addition, an important element determining the size of the competitive advantage is local business networks embeddedness.

Keywords: competitiveness, early-internationalized firms, international new ventures, born globals, early internationalisation 